\title{
Investigation of the covalent binding of styrene-7,8-oxide to DNA in rat and mouse
}

\author{
Cantoreggi, S ; Lutz, W K
}

\begin{abstract}
Styrene-7,8-oxide (SO), the main intermediate metabolite of styrene, induces hyperkeratosis and tumors in the fore-stomach of rats and mice upon chronic administration by gavage. The aim of this study was to investigate whether DNA binding could be responsible for the carcinogenic effect observed. [7-3H]SO was administered by oral gavage in corn oil to male CD rats at two dose levels (1.65 or 240 $\mathrm{mg} / \mathrm{kg}$ ). After 4 or $24 \mathrm{~h}$, forestomach, glandular stomach and liver were excised, DNA was isolated and its radioactivity determined. At the $4 \mathrm{~h}$ time point, the DNA radioactivity was below the limit of detection in the forestomach and the liver. Expressed in the units of the covalent binding index, CBI $=(\mathrm{mol}$ adduct/mol DNA nucleotide)/(mmol chemical administered/kg body wt), the DNA-binding potency was below 2.6 and 2.0 respectively. In the glandular stomach at $4 \mathrm{~h}$, and in most $24 \mathrm{~h}$ samples, DNA was slightly radiolabeled. Enzymatic degradation of the DNA and separation by HPLC of the normal nucleotides showed that the DNA radioactivity represented biosynthetic incorporation of radiolabel into newly synthesized DNA. The limit of detection of DNA adducts in the glandular stomach was 1.0. In a second experiment, [7-3H]SO was administered by i.p. injection to male B6C3F1 mice. Liver DNA was analyzed after $2 \mathrm{~h}$. No radioactivity was detectable at a limit of detection of CBI $<0.6$. In agreement with the relatively long half-life of SO in animals, the chemical reactivity of SO appears to be too low to result in a detectable production of DNA adducts in an in vivo situation. Upon comparison with the DNA-binding of other carcinogens, a purely genotoxic mechanism of tumorigenic action of SO is unlikely. The observed tumorigenic potency in the forestomach could be the result of strong tumor promotion by high-dose cytotoxicity followed by regenerative hyperplasia
\end{abstract}

DOI: https://doi.org/10.1093/carcin/13.2.193

Posted at the Zurich Open Repository and Archive, University of Zurich

ZORA URL: https://doi.org/10.5167/uzh-154124

Journal Article

Published Version

Originally published at:

Cantoreggi, S; Lutz, W K (1992). Investigation of the covalent binding of styrene-7,8-oxide to DNA in rat and mouse. Carcinogenesis, 13(2):193-197.

DOI: https://doi.org/10.1093/carcin/13.2.193 


\section{Investigation of the covalent binding of styrene-7,8-oxide to DNA in rat and mouse}

\author{
S.Cantoreggi and W.K.Lutz ${ }^{1}$ \\ Institute of Toxicology, Swiss Federal Institute of Technology and \\ University of Zurich, CH-8603 Schwerzenbach, Switzerland \\ 'To whom correspondence should be addressed
}

Styrene-7,8-oxide (SO), the main intermediate metabolite of styrene, induces hyperkeratosis and tumors in the forestomach of rats and mice upon chronic administration by gavage. The aim of this study was to investigate whether DNA binding could be responsible for the carcinogenic effect observed. $\left[{ }^{3}-\mathrm{H}\right] \mathrm{SO}$ was administered by oral gavage in corn oil to male CD rats at two dose levels $(1.65$ or $240 \mathrm{mg} / \mathrm{kg})$. After 4 or $24 \mathrm{~h}$, forestomach, glandular stomach and liver were excised, DNA was isolated and its radioactivity determined. At the $4 \mathrm{~h}$ time point, the DNA radioactivity was below the limit of detection in the forestomach and the liver. Expressed in the units of the covalent binding index, $\mathrm{CBI}=$ ( $\mu \mathrm{mol}$ adduct $/ \mathrm{mol}$ DNA nucleotide) $/(\mathrm{mmol}$ chemical administered/kg body wt), the DNA-binding potency was below 2.6 and 2.0 respectively. In the glandular stomach at $4 \mathrm{~h}$, and in most $24 \mathrm{~h}$ samples, DNA was slightly radiolabeled. Enzymatic degradation of the DNA and separation by HPLC of the normal nucleotides showed that the DNA radioactivity represented biosynthetic incorporation of radiolabel into newly synthesized DNA. The limit of detection of DNA adducts in the glandular stomach was 1.0. In a second experiment, $\left[7^{-}{ }^{3} \mathrm{H}\right] \mathrm{SO}$ was administered by i.p. injection to male B6C3F1 mice. Liver DNA was analyzed after $2 \mathrm{~h}$. No radioactivity was detectable at a limit of detection of CBI $<0.6$. In agreement with the relatively long half-life of SO in animals, the chemical reactivity of SO appears to be too low to result in a detectable production of DNA adducts in an in vivo situation. Upon comparison with the DNA-binding of other carcinogens, a purely genotoxic mechanism of tumorigenic action of SO is unlikely. The observed tumorigenic potency in the forestomach could be the result of strong tumor promotion by high-dose cytotoxicity followed by regenerative hyperplasia.

\section{Introduction}

Styrene is a widely used plastic monomer. Exposure of humans occurs at the workplace and, at a much lower level, from polluted air and monomer residues in polystyrene (1). Because of the structural similarity with the carcinogen vinyl chloride, the carcinogenic potential of styrene was examined. An LARC Working group concluded that styrene is possibly carcinogenic to humans (2). This classification was based on inadequate evidence for carcinogenicity to humans and on limited evidence for carcinogenicity to animals. In the latter, organs with high spontaneous tumor incidence appeared to be affected (mouse: lung and liver). The overall classification of styrene was also based

*Abbrevlations: SO, styrene-7,8-oxide; HA, hydroxyapatite; CBI, covalent binding index.

(C) Oxford University Press on the sufficient evidence for the carcinogenicity of styrene-7,8-oxide (SO*), the major intermediate metabolite in vivo: with oral gavage of SO, forestomach tumors were induced in both rats and mice (3-5).

The genetic toxicology of styrene and SO has been reviewed recently (6). SO was mutagenic in a number of test systems without metabolic activation. DNA adduct formation in vitro has also been investigated extensively by Hemminki and co-workers ( 7 , and references therein). In vivo, only one publication reports on the identification of a guanyl-7 adduct in liver DNA isolated from mice after i.p. administration of tritiated SO (8). A quantitative analysis of the overall DNA-binding potency of SO is not possible, however, on the basis of these results.

SO is a relatively stable epoxide. The half-life of SO in the blood is $\sim 20 \mathrm{~min}$ in the rat (9). This means that the reaction with the weak nucleophilic centers in DNA must be slow. On the other hand, binding to nucleophilic groups in proteins is expected to be more rapid. Protein binding would also explain the cytotoxicity and regenerative hyperplasia that accompany tumor induction by SO in the forestomach. Since stimulation of cell division is known to be a strong promoting factor in carcinogenesis (10), it is not known to what extent tumor induction in the forestomach was due to DNA binding.

In this study, the covalent binding of tritiated SO to DNA is investigated in vivo and the data are analyzed in terms of a DNAbinding potency. On the basis of a comparison with other carcinogens, the contribution of DNA binding to the tumorigenic potency of SO in the forestomach is evaluated.

\section{Materials and methods}

Chemicals

[7- $\left.{ }^{3} \mathrm{H}\right]$ Styrene-7,8-oxide (mol. wt 120.15) was purchased from The Radiochemical Centre, Amersham, UK. The specific activity was $105 \mathrm{mCi} / \mathrm{mm}$. $(0.875 \mathrm{mCi} / \mathrm{mg})$. It was stored at $-20^{\circ} \mathrm{C}$ and used within 2 months after delivery. The radiochemical purity of the compound in the application solution was checked by HPLC on a $250 \times 8 \mathrm{~mm}$ column, filled with Lichrosorb RP18 $7 \mu$, with a distilled water/acetonitrile gradient $(0 \mathrm{~min}$ : $30 \%$ acetonitrile, $60 \mathrm{~min}: 100 \%$ acetonitrile), at a flow rate of $3.5 \mathrm{~mL} / \mathrm{min}$. A solution of styrene/SO/styrene glycol $(1: 4: 4)$ in acetonitrile was injected as standard. The radiochemical purity was determined to be $93.2 \%$.

SO, DMSO, and calf thymus DNA were obtained from Fluka AG, Buchs SG, Switzerland. Com oil, purchased in a local retail shop, was from Kentaur-Nuxo AG, Burgdorf Switzerland.

Animals and treatments

Male CH:CD ${ }^{R} \mathrm{BR}$ rats and male B6C3F1/CriBR mice from Charles River Wiga, Sulzfeld FRG were used. They were acclimatized in Macrolon cages for at least 1 week after delivery and were fed ad libirum with tap water and maintenance diet NAFAG 890, purchased from Nafag AG, Gossau SG, Switzerland.

Application solutions

The ampoule containing the radiolabeled compound was cooled at the bottom with liquid nitrogen and cut open. $\left[7-{ }^{3} \mathrm{H}\right] \mathrm{SO}$ was dissolved in DMSO and, depending on the required chemical dose, unlabeled SO was added. The solution was transferred into a glass test tube and diluted with corn oil. The ratio DMSO/SO/com oil was 1:1:4, 1:250:1500 and 1:1:18, for the experiments with rats at high and low dose, and with mice respectively.

The radioactivity in the application solution was determined by scintillation counting of an aliquot diluted into toluene.

The unfasted rats received $\sim 0.5 \mathrm{ml}$ of the application solution by oral gavage early in the moming. The exact dose was determined by the weight difference 
of the syringe and is shown in Table I. Control rats received $0.5 \mathrm{ml}$ com oil. Four mice received $-70 \mu$ lof the application solution by i.p. administration, resulting in a mean dose of $165 \mathrm{mg} / \mathrm{kg}\left(3.2 \times 10^{9}\right.$ d.p.m. $\left./ \mathrm{kg}\right)$. Two control mice received $200 \mu \mathrm{l}$ corn oil.

The rats were killed with ether 4 or $24 \mathrm{~h}$ after the administration. The mice were killed with ether $2 \mathrm{~h}$ after the administration. Organs of interest were excised, pooled into groups of three (except for the liver) and kept frozen at $-20^{\circ} \mathrm{C}$.

\section{Isolation of DNA and chromatin protein}

DNA and chromatin protein were isolated from selected organs via a chromatin fraction according to Sagelsdorff et al. (11). The DNA of the $24 \mathrm{~h} / \mathrm{low}$ dose was repetitively purified according to Sagelsdorff $e$ al. (11). The DNA from the other experiments was repurified by hydroxyapatite (HA) adsorption chromatography:dry HA $(1 \mathrm{~g} / \mathrm{mg}$ DNA) was suspended overnight in filtered MUP ( $8 \mathrm{M}$ urea, 0.24 $M$ sodium phosphate buffer, $\mathrm{pH} 6.8$ ), the slurry was swirled and poured into a $25 \times 120 \mathrm{~mm}$ glass column and the MUP was allowed to run off. The DNA solution was loaded on the column and the elution monitored at $260 \mathrm{~nm}$. The column was washed with MUP at a flow rate of $1-2 \mathrm{ml} / \mathrm{min}$ by gravity until the absorbance had returned to background value. The urea was then purged with $14 \mathrm{mM}$ sodium phosphate, $\mathrm{pH} 6.8$, and the DNA eluted with $0.48 \mathrm{mM}$ sodium phosphate, $\mathrm{pH}$ 6.8. The collected eluate was dialyzed at $4^{\circ} \mathrm{C}$ against $2 \times 10 \mathrm{I}$ $0.2 \mathrm{M}$ sodium chloride for 12 and $24 \mathrm{~h}$. The DNA concentration, as determined by optical density, was usually high enough for direct scintillation counting.

Control experiments were performed using DNA isolated from untreated anumals. The radioactivity counts-upon comparison with historical controlswere used to show that the work-up of the DNA samples was performed without external contamination with radiolabel.

In vitro incubation of calf thymus DNA with $[7-3 \mathrm{H}] \mathrm{SO}$

Calf thymus DNA was purified according to the method described above in order to remove residual protein. A $220 \mu \mathrm{l}(150 \mu \mathrm{Ci})$ portion of the application solution remaining from the rat $24 \mathrm{~h} /$ low dose experiment and $500 \mu \mathrm{l} 1 \%$ SDS in $14 \mathrm{mM}$ sodium phosphate, $\mathrm{pH} 6.8$, were added to $14 \mathrm{mg}$ calf thymus DNA dissolved in $10 \mathrm{ml} 8 \mathrm{mM}$ calcium chloride, $20 \mathrm{mM}$ sodium suocinate, $\mathrm{pH} 6.0$. The mixture was incubated for $24 \mathrm{~h}$ at $37^{\circ} \mathrm{C}, 20 \mathrm{ml}$ ethanol was added and the solution kept at $-20^{\circ} \mathrm{C}$ for 4 days. The precipitated DNA was centrifuged at $1000 \mathrm{~g}$, the supernatant discarded, and the pellet redissolved in $26 \mathrm{ml}$ calcium succinate buffer. The solution was dialyzed overnight against $1010.2 \mathrm{M}$ sodium chloride, extracted twice with phenol/chloroform/isoamyl alcohol (25:25:1) and twice with ether to remove phenol, and was dialyzed again. The DNA was precipitated with ethanol and kept at $-20^{\circ} \mathrm{C}$ for 3 weeks, centrifuged at $1000 \mathrm{~g}$, the supernatant discarded, and the pellet dissolved in $15 \mathrm{ml}$ calcium succinate buffer. The optical density and the specific activity were measured.
The DNA was punfied repetitively (four times) by ethanol precipitation and dialysis to constant specific activity.

\section{HPLC analysis of the nucleorides}

DNA was digested according to Sagelsdorff et al. (12). The resulting deoxynucleotides were separated by HPLC on an Eurosphere RP18 $5 \mu$ column $(250 \times 4 \mathrm{~mm}$ ) with a flow of $2 \mathrm{ml} / \mathrm{min} 30 \mathrm{mM}$ ammonium formate buffer,

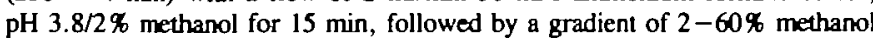
in $25 \mathrm{~min}, 60-2 \%$ methanol in $10 \mathrm{~min}$ and $2 \%$ methanol for $15 \mathrm{~min}$. The optical density of the eluate was recorded at $254 \mathrm{~nm}$. Two munute fractions of digested in vitro DNA were collected. Based on optical density and radioactivity patterns, six fractions of digested in vivo DNA were collected. Fraction 1 (0-2 min): fromt; fraction 2 (2-10 min): natural nucleotides; fraction $3(10-16 \mathrm{~min})$ : between natural nucleotides and adkucts; fraction 4 (16-26 min): adducts; fraction 5 (26-36 min): adducts; fraction 6 ( $36-46 \mathrm{~min})$ : after adducts. The fractions were freeze-dried, dissolved in $1 \mathrm{ml}$ water and counted.

\section{Scintillation counting}

DNA samples were counted in $10 \mathrm{ml}$ Instagel (Packard) for $3 \times 30 \mathrm{~min}$. The significance level at 2 standard deviations, given by the Poisson distribution of the radioactive decay plus vial-to-vial differences, had been determined to be 2.6 c.p.m. in the tritium channel. The counting efficiency ranged between 28 and $32 \%$.

The nucleatide fractions from the HPLC analyses were counted in $10 \mathrm{ml}$ Ultima Gold (Packard) in plastic vials for $\mathbf{4 5} \mathrm{mn}$. The significance level had been determined to be 1.0 c.p.m. in an optimized tritium channel. The counting efficiency was $48 \%$. The net radioactuvity was calculated by subtracting the radioactivity of an equivalent sample isolated from anımals treated with vehicle only, both for DNA samples and for fractions of the nucleotides analyses.

\section{Calculations}

The concentration of a DNA solution was calculated from the optical density of a diluted aliquot at $260 \mathrm{~nm}$ using an absorbance of 20 for $1 \mathrm{mg} \mathrm{DNA} / \mathrm{ml}$. Depending on the amount of DNA available, an aliquot corresponding to 0 25-1 mg DNA was taken, diluted with calcium succinate buffer to a standardized concentration (usually the concentration of the most diluted sample of the ongoing experiment), added to $10 \mathrm{ml}$ Instagel, and counted.

The concentration of the nucleotide solutions was calculated from the optical density of a diluted aliquot at $260 \mathrm{~nm}$ using an absortance of 35 for a nucleotide mixture equivalent to $1 \mathrm{mg}$ digested DNA/ml. The specific DNA radioactivity was expressed as DNA binding per dose administered, by conversion to the units of the covalent binding index, CBI $=\mu \mathrm{mol}$ SO bound per mol DNA nucleotide/mmol SO adminustered per kg body wt (13).

Table I. Investigation of the covalent binding of $\left[7^{3}{ }^{3} \mathrm{H}\right] \mathrm{SO}$ to DNA isolated from the forestomach of male CD rats after oral administration

\begin{tabular}{|c|c|c|c|c|c|c|c|c|}
\hline \multirow{4}{*}{$\begin{aligned} & \text { Dose" }(\mathrm{mg} / \mathrm{kg}) \\
&\left(10^{9} \text { d.p.m. } / \mathrm{kg}\right)\end{aligned}$} & \multicolumn{8}{|l|}{ Time/dose } \\
\hline & 4 hlow dose & & $4 \mathrm{~h} / \mathrm{high}$ dose & & 24 h/low dose & & $24 \mathrm{~h} / \mathrm{high}$ dose & \\
\hline & 1.65 & 1.78 & 232 & 255 & 1.66 & 1.52 & 242 & 218 \\
\hline & 3.17 & 3.42 & 2.11 & 2.33 & 3.23 & 2.90 & 2.21 & 1.98 \\
\hline $\begin{array}{l}\text { DNA sp. act } \\
\text { first purification }\end{array}$ & & & & & & & & \\
\hline $\begin{array}{l}\text { (d.p.m./mg) } \\
\text { (CBI units) }^{\text {b }}\end{array}$ & 49.9 & 57.8 & 62.9 & 94.8 & $\begin{array}{l}53.5 \\
\leq 5.1\end{array}$ & $\begin{array}{r}35.2 \\
\leq 3.7\end{array}$ & 170.5 & 75.9 \\
\hline Repetitive purification ${ }^{\mathrm{c}}$ & & & & & & & & \\
\hline $\begin{array}{l}\text { (d.p.m./mg) } \\
\text { (CBI units) }\end{array}$ & $\begin{array}{l}<28.8 \\
<2.8\end{array}$ & $\begin{array}{r}<28.8 \\
<2.6\end{array}$ & $\begin{array}{r}<22.8 \\
<3.4\end{array}$ & $\begin{array}{r}<39.4 \\
<5.3\end{array}$ & & & 51.2 & 24.4 \\
\hline $\begin{array}{l}\text { Nucleotide analysis } \\
\text { Recovery of }\end{array}$ & & & & & & & 76 & $\mathrm{ND}$ \\
\hline $\begin{array}{l}\text { optical density (5) } \\
\text { Radioactivity } \\
\text { eluting with }\end{array}$ & & & & & & & 10 & D \\
\hline $\begin{array}{l}\text { optical density (\%) } \\
\text { Radioactivity } \\
\text { cluting without }\end{array}$ & & & & & & & 66 & 71 \\
\hline $\begin{array}{l}\text { optical density (\%) } \\
\text { Covalent DNA binding }\end{array}$ & & & & & & & $<34$ & $<29$ \\
\hline (CBI units) & & & & & & & $<6.5$ & $<2.5$ \\
\hline
\end{tabular}

Means of pools of three rats.

${ }^{b} \mathrm{CBI}$ unit defined as DNA binding per dose: $\mathrm{CBI}=(\mu \mathrm{mol}$ chemical bound $/ \mathrm{mol}$ DNA nucleotide) $/(\mathrm{mmol}$ chemical administered $/ \mathrm{kg}$ body wt).

'No DNA left in $24 \mathrm{~h} /$ low dose samples. 


\section{Results}

\section{Reaction of $\left[7_{-}^{3} \mathrm{H}\right] \mathrm{SO}$ with DNA in vitro}

The aim of this study was to investigate the DNA binding potency of SO in vivo. For the analysis of DNA isolated from animal organs, therefore, the chromatographic properties of $\mathrm{SO}-$ nucleotide adducts had to be known from in vitro reactions.

Incubation of tritiated SO with DNA in vitro resulted in a DNA that contained irreversibly bound radioactivity. On the basis of the specific activity of SO used, the level of DNA adducts was calculated to be $10 \mathrm{SO}$-nucleotide adducts $/ 10^{6}$ nucleotides. The fraction of SO that had reacted with DNA under these conditions was as little as $0.03 \%$, indicating the low electrophilic reactivity of this epoxide.

Enzymatic degradation of the DNA and separation of the 3 '-nucleotides by HPLC revealed that the radioactivity eluted distant from the normal nucleotides and nucleosides (Figure 1). In agreement with the literature (7), a number of different $\mathrm{SO}$-nucleotide adducts must be expected.

In vivo DNA binding of SO in the rat after oral administration In the first set of in vivo experiments, rats were treated by oral gavage at two dose levels. The high dose corresponded to a dose used in the carcinogenicity bioassays; the low dose was $>100$ times lower and was used to investigate any dose-dependent differences in SO metabolism. DNA was analyzed 4 or $24 \mathrm{~h}$ postdosage. According to the kinetics established, all SO is expected to be absorbed and metabolized within $4 \mathrm{~h} \mathrm{(9)}$. At this time point, DNA binding is therefore expected to be close to its maximum value. The $24 \mathrm{~h}$ point was taken to show the rate of removal and repair of putative DNA adducts.

The purification of DNA from non-covalently bound radioactivity is crucial in this type of experiment when up to half a millicurie are administered per animal. Therefore, whenever a DNA sample contained measurable radioactivity and enough DNA was available, purification was repeated until constant specific activity was reached.

Table I summarizes the data obtained from the target organ for tumor induction, the forestomach. At $4 \mathrm{~h}$ after the administration, the DNA did not contain measurable radioactivity. Using our limit of detection of 2.6 c.p.m. radioactivity per glass

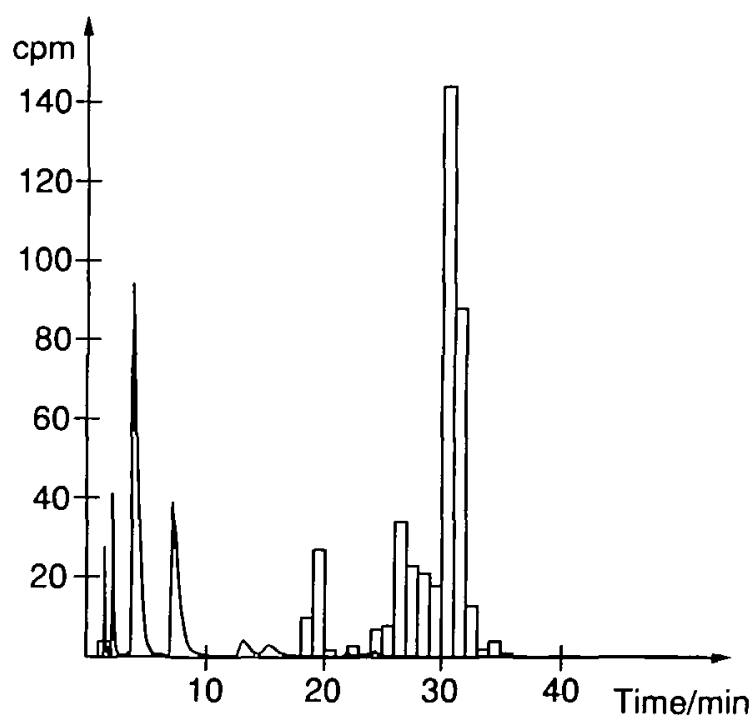

Fig. 1. Reverse-phase HPLC profiles of optical density (solid line) and tritium radioactivity (bars; c.p.m.) of deoxyribonucleotides obtained by enzymatic hydrolysis of calf thymus DNA after incubation with $\left[7-{ }^{3} \mathrm{H}\right] \mathrm{SO}$. scintillation vial, the DNA binding potency, expressed in the units of the $\mathrm{CBI}$, was $<2.6$. At $24 \mathrm{~h}$ post-dosage, radioactivity was detectable in all DNA samples. It is highly unlikely that this radioactivity can be attributed to DNA adduct formation, because all SO administered should have been metabolized within the first $4 \mathrm{~h}$. No additional adducts are therefore expected to be formed between 4 and $24 \mathrm{~h}$. The radioactivity detected after $24 \mathrm{~h}$ more likely represents biosynthetic incorporation of radiolabel into newly synthesized DNA. For instance, tritiated water is formed when the tritium label of the 7-position of the tritiated SO is released during the oxidation of mandelic acid to benzoic acid or phenylglyoxylic acid. A tritium atom can be incorporated into DNA when, for instance, the hydroxyl group in the 2 '-position of the ribonucleotides is replaced by a hydrogen atom to form the 2'-deoxyribonucleotides.

In order to show positively the biosynthetic incorporation of radiolabel into the normal nucleotides, DNA isolated from the forestomach, $24 \mathrm{~h}$ after administration of the high dose of SO, was degraded to the 3 '-nucleotides, which were analyzed by HPLC (Figure 2). All detectable radioactivity eluted together with the normal nucleotides. No significant radioactivity was seen at elution times known for the adducts formed in vitro between SO and DNA. The limit of detection shown in the last column of Table I was calculated on the assumption that an adduct could be divided into two fractions ( 2 c.p.m.).

In the glandular stomach (which was not a target organ for tumor induction), the situation was similar to the forestomach. Thanks to the higher yield to DNA from this portion of the stomach, the limit of detection to exclude DNA adduct formation was even somewhat better than in the forestomach (CBI < 1.5). Again, in all DNA samples that were detectably radiolabeled ( $4 \mathrm{~h} /$ low dose and $24 \mathrm{~h} / \mathrm{high}$ dose), the DNA radioactivity was localized in the fractions containing the normal nucleotides (data not shown). The resulting limit of detection of DNA adduct formation was at CBI $<1.0$.

In the DNA isolated from the livers, the first purification round already resulted in a limit of detection CBI $<2$ in all but the $24 \mathrm{~h} /$ low dose sample. In this sample, repetitive purification removed the residual DNA-associated radioactivity and a limit of detection of $\mathrm{CBI}<0.6$ was derived from counting all available DNA sample.

In vivo DNA binding of SO in the mouse after i.p. administration While $\mathrm{SO}$ is quite stable in neutral aqueous media, the hydrolysis is much faster in acid (9). It is therefore conceivable that orally

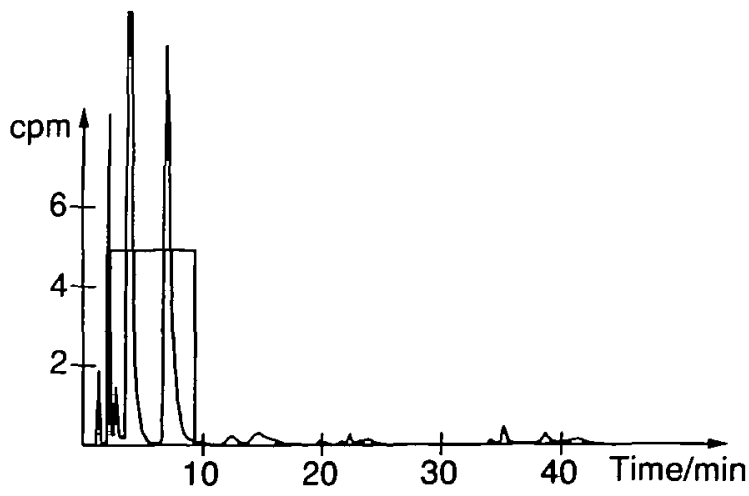

Fig. 2. Reverse-phase HPLC profiles of optical density (solid line) and tritium radioactivity (bars; c.p.m.) of deoxyribonucleotides obtained by enzymatic hydrolysis of DNA isolated from the forestomachs of a pool of three male $\mathrm{Crl}: \mathrm{CD}^{\mathrm{R}} \mathrm{BR}$ rats $24 \mathrm{~h}$ after p.o. administration of $2.2 \times 10^{9}$ d.p.m. $/ \mathrm{kg}(242 \mathrm{mg} / \mathrm{kg})\left[7-{ }^{3} \mathrm{H}\right] \mathrm{SO}$. 
administered SO is hydrolyzed to a certain extent in the stomach so that the dose reaching the liver is only a fraction of the administered dose. The limit of detection of DNA binding in the liver would then not be as low as indicated because the CBI expresses DNA damage per dose.

In a second experiment, therefore, SO was administered by i.p. injection in order to circumvent the acidic milieu of the stomach. Mice were used for this experiment and the period of observation was $2 \mathrm{~h}$ so that the data are directly comparable with the data published by Nordqvist et al. (8).

No DNA sample isolated from the liver contained measurable DNA radioactivity after the first purification round. In CBI units, upper limit values of 0.6 resulted. This value supports our negative data obtained in the rat but is $\sim 40$ times lower than the CBI value for mouse liver DNA estimated from one chromatogram shown in the paper of Nordqvist et al. (8).

\section{Discussion}

SO did not produce detectable DNA adducts in the target organ for tumor induction. The limit of detection in the low-dose experiment was at 7 adducts $/ 10^{8}$ nucleotides in the forestomach DNA. In vitro, after a $24 \mathrm{~h}$ incubation of tritiated SO with calf thymus DNA, adducts had been formed to a minor but measurable extent. It is therefore probable that a few adducts will have been formed in vivo also. The question is whether these few DNA adducts below the limit of detection can be responsible for the tumors induced in the forestomach after chronic oral gavage of SO.

In the carcinogenicity studies, toxicity and regenerative hyperplasia have been observed in the forestomach (5). Stimulated cell division is being discussed increasingly as a cause of cancer by itself (10) under the assumption that it accelerates the accumulation of mutations from spontaneous DNA damage (14). An increased tumor incidence is therefore possible in the absence of a DNA-damaging chemical.

The above discussion is valid only if two requirements are met. Firstly, adducts formed in vivo must be chemically stable during DNA purification. Some guanyl-7 adducts are known to be chemically labile, especially at acid $\mathrm{pH}$. For the respective SO adducts in the form of mononucleotides, the half-life has been described to be $\sim 4 \mathrm{~h}$ (16). In double-stranded DNA, however, these adducts were considered 'not particularly labile', on the basis of a half-life of 10 days at $\mathrm{pH} 4.2$ and room temperature (7). Furthermore, about one-quarter of the adducts are formed at positions other than the 7-nitrogen of guanine and are chemically stable (7). At the worst, therefore, our limit of detection has to be multiplied by a factor of 4 , under the extreme assumption that all guanyl-7 adducts are lost during DNA purification.

Secondly, the limit of detection must be below the CBI of comparable genotoxic carcinogens. For instance, 1,2-dichloroethane produced forestomach tumors in rats after administration by oral gavage with a carcinogenic potency similar to that of SO (17). On the other hand, DNA-binding experiments reported by Reitz et al. (18) showed CBI values of 7 in the stomach and 18 in the liver, i.e. DNA-binding potencies higher than our limit of detection for SO by a factor of $>5$ to $>30$. This indicates that the carcinogenic potency of $\mathrm{SO}$ is probably based on promoting factors acting in addition to an undetectable DNAbinding potency. This discussion holds only if the pattern of DNA adducts formed by SO and 1,2-dichloroethane have similar mutational consequences. This question cannot be addressed experimentally if the level of adducts is below the limit of detection. The possibility that an undetectable DNA adduct is extremely dangerous is small but can never be excluded.

It is concluded that a purely genotoxic mechanism of tumorigenic action of SO is unlikely. The observed tumorigenic potency in the forestomach is probably the result of strong tumor promotion by regenerative hyperplasia.

The question now arises whether these data can also be used to interpret the carcinogenicity studies with styrene. SO is the main intermediate metabolite of styrene. The relative stability of SO towards DNA could therefore indicate that the parent compound styrene cannot show a high CBI, either. However, a minor fraction of the styrene metabolism $(<1 \%)$ involves the formation of 4-vinylphenol, probably via an intermediate 3,4-epoxide $(19,20)$. The DNA-binding potency of this epoxide is not known. It is further not known whether SO formed from styrene intracellularly can result in a higher concentration near DNA than SO entering from outside. Therefore, DNA binding studies with styrene will have to be performed to interpret in a manner similar to SO the carcinogenicity studies with the parent compound styrene.

\section{Acknowledgement}

This work was supported by ECETOC, the European Chemical Industry Ecology and Toxicology Centre.

\section{References}

1. WHO Task Group (1983) Styrene. Environ. Health Criteria, 26, 1-123.

2. IARC (1987) LARC Monographs on the Evaluation of Carcinogenic Risks to Humans. IARC, Lyon, Supplement 7, pp. 345-347.

3. Maltoni,C., Failla,G. and Kassapidis,G. (1979) First expenmental demonstration of the carcinogenic effects of styrene oxide. Med.Lav., 5 , $358-362$.

4. Ponomarkov,V., Cabral,J.R.P., Wahrendorf,J. and Galendo,D. (1984) A carcinogenicity study of styrene-7,8-oxide in rats. Cancer Lett., 24, 95-101.

5. Lijinsky, W. (1986) Rat and mouse forestomach tumors induced by chronic oral administration of styrene oxide. J. Natl. Cancer Inst., 77, 471-476.

6. Barale,R. (1991) The genetic toxicology of styrene and styrene oxide. Mutat. Res., 257, $107-126$.

7. Vodicka,P. and Hemmınki,K. (1988) Identification of alkylatıon products of styrene oxide in single- and double-stranded DNA. Carcinogenesis, 9, $1657-1660$.

8. Nordqvist,M.B., Loef,A., Osterman-Golkar,S. and Walles,S.A.S. (1985) Covalent binding of styrene and styrene-7,8-oxide to plasma proteins, hemoglobin and DNA in the mouse. Chem.-Biol. Interactions, 55, 63-73.

9. Schwegler,U., Jiang,X., Kessler,W., Johanson,G. and Filser,J.G. (1990) Pharmakokinetik von Styrol bei Ratte und Maus und Bestimmung von Styrol-7,8-oxid im Blut von Ratten. In Schuckmann,F. and SchopperJochum,S. (eds), Berufskrankheiten, Krebserzeugende Ambeitsstoffe, Biological Monitoring. Gentner Verlag, Stuttgart, pp. 419-425.

10. Preston-Martin,S., Pike,M.C., Ross,R.K., Jones,P.A. and Henderson,P.E. (1990) Increased cell division as a cause of human cancer. Cancer Res., 50 , $7415-7421$.

11. Sagelsdoff,,P., Lutz,W.K. and Schlatter,C. (1983) The relevance of covalent binding to mouse liver DNA to the carcinogenic action of hexachlorocyclohexane isomers. Carcinogenesis, 4, 1267-1273.

12. Sagelsdorf,P., Lutz,W.K. and Schlatter,C. (1988) DNA methylation in rat liver by daminozide, 1,1-dimethylhydrazine, and dimethylnitrosamine. Fundam. Appl. Toxicol., 11, 723-730.

13. Lutz,W.K. (1979) In viw covalent binding of organic chemicals to DNA as a quantitative indicator in the process of chemical carcinogenesis. Mutar. Res , $65,289-356$.

14. Lutz,W.K. (1990) Endogenous genotoxic agents and processes as a basis of spontaneous carcinogenesis. Mutat. Res., 238, 287-295.

15. Lutz,W.K. (1990) Dose-response relationship and low dose extrapolation in chemical carcinogenesis. Carcinogenesis, 11, 1243-1247.

16. Hemminki,K., Alhonen-Raatesalmi,A., Koivisto,P. and Vodicka,P. (1990) Synthesis and stability of 2'-deoxyguanosine 3'-monophosphate adducts of dimethyl sulfate, ethylene oxide and styrene oxide. Chem.-Biol. Interactions, $75,281-292$.

17. Gold,L.S., Slone,T.H., Backman,G.M., Magaw,R., Da Costa,M., Lopipero,P., Blumenthal,M. and Ames,B.N. (1987) Second chronological 
supplement to the carcinogenic potency database: standardized results of animal bioassays published through December 1984 and by the National Toxicology Program through May 1986. Environ. Health Perspect., 74, 237-329.

18. Reit,,R.H., Fox,T.R., Ramsey,J.C., Quast,J.F., Langvardt,P.W. and Watanabe,P.G. (1982) Phamacokinetics and macromolecular interactions of ethylene dichloride in rats after inhalation or gavage. Toxicol. Appl. Pharmacol., 62, 190-204.

19. Pantarotto,C., Fanelli,R., Bidoli,F., Morazzoni,P., Salmona,M. and Szczawinska,K. (1978) Arene oxides in styrene metabolism, a new perspective in styrene toxicity? Scand. J. Wort Enviran. Health, 4, 67-77.

20. Pfäfli,P., Hesso,A., Vainio,H. and Hyvőnen,M. (1981) 4-Vinylphenol excretion suggestive of arene oxide formation in workers occupationally exposed to styrene. Taxicol. Appl. Phamacol., 60, 85-90.

Received on June 26, 1991; revised on October 7, 1991; accepted on November 7, 1991 